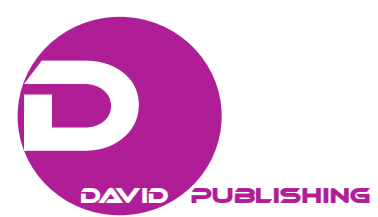

\title{
Is the Grass Greener on the Other Side? Work-Related Migration From Western-Hungary to Austria
}

\author{
Előd Kovács \\ Széchenyi István University, Győr, Hungary
}

\begin{abstract}
After the 2004 EU accession of Hungary, the evolvement of the cross-border regions has started to emerge there as well, followed by the decrease - and in case of the Schengen Area the complete break off - of the separation role of the borders as a result of which the citizens of the member states have free movement in the greater part of the European Union. The basic goal of the EU enlargement was the establishment of the free movement of capital, goods, information, and workers. A very strong workforce migration has immediately started and is still ongoing among the EU member states, directing in first row from the less developed economies to the better developed ones. This of course is the same in case of Hungary, where the active population in a rapidly growing number makes the decision to take a job in the well-developed countries of the EU for a shorter or longer period. According to Rechnitzer, people living in the Austrian-Hungarian border region (among whom many were Hungarian citizens) were capable of novation and were active performers in general already before the transition period. The study focuses on the key motivation factors and the possible grouping of the people living in Western-Hungary having decided to work in Austria.
\end{abstract}

Keywords: Austria, labour market, migrants, key motivational factors

\section{The EU Faces New Challenges}

In the great majority of the European nation-states, the aging of societies is typical; the ratio of elder generations within the total population is getting larger and larger. In the next couple of decades, this trend is expected to keep on going, which challenges the nation-states. Current population forecasts count with advanced labour force, population aging, and a drop in the number of those belonging to the active population (Van der Gaag \& Van der Erf, 2008; EU, 2012). The forecasted aging of the population has a serious effect on not only the outlook of the stability of the pension system, but also endangers the health and social care systems. It also influences the labor market and the living conditions of the people (Kotowska, 2006; Prskawetz et al., 2008). In the last few years, the EU had to face new challenges unexpectedly. The first one is the mass-migration of refugees heading towards the EU from outside its borders trying to escape from war; but also the number of those economic migrants targeting the well-developed EU member states coming from the poor countries (mainly in Africa) has been multiplied. Politicians of the individual EU countries see these issues quite differently. The anti-migration politics builds on the justified and causeless fears as well and supports the

Előd Kovács, Ph.D. candidate, Doctoral School of Regional and Economic Sciences, Széchenyi István University, Győr, Hungary.

Correspondence concerning this article should be addressed to Előd Kovács, EQQ Equities Ltd., H-9789 Sé, Mátyás király u. 4 , Hungary. 
reclusion. In the politics of many member states, the "swing to the rigt" can be observed. While at the same time, the common report of the OECD \& EU (2014) attracts the attention to the utilization of the potential hiding in the workforce migration. Based on the findings of the analysis, being on the way out of the hard times caused by the 2008 world economic crisis, the EU could stand on much more stabile feet if it would exploit the skills and knowledge of the migrant workforce.

\section{The Situation of Hungary as $\mathrm{COO}$}

The type of system settled in Hungary in the times of socialism has left a very diverse labour market. The transition period has brought mass unemployment which the state tried to ease with the implementation of the unemployment benefit and the restructuring of the retirement system. With the slow stabilization of the economy sometimes stopped by the smaller or bigger economic crisis, followed by the chance of getting employed abroad arising with the EU membership and later with the expansion of public work program, the Hungarian labour market has undergone drastical changes. Hungary is very much a sender country in terms of work related migration. It still has a dual economy, and the public work program indeed has mainly a social goal and focus, debiting the budget of the state instead of being profitable (Barta \& Kovács, 2017). The aging of the population in Hungary is a critical issue. In the last couple of years, a new situation has emerged on the Hungarian labor market: the torturing shortage of labour.

The wages in the public sector kept on a relatively low level for over many years; the spread of minimum wage workplaces and the starvation wages of the public work program all effect on the wage levels of the private sector. The Hungarian wage levels do not only lag behind the EU average, but also tail off that of the neighbouring countries. Due to the fact that the wages are much lower than in the neighbouring countries, Hungarians decide to (and actually do) work abroad in massive quantities. The processes of the Hungarian labour market were of course deeply influenced by the complete opening of the Austrian labor market in 2011, which has resulted in the work related migration of many active members of the younger generation to Austria (Barta \& Kovács, 2017); in 2012, the most people migrating there come already from Hungary (ÖIF, 2014). Out of the estimated 500,000 Hungarians working abroad (World Bank, 2011), 94,550 Hungarians are legally working in Austria (Hauptverband der Österreichischen Sozialverischerungsträger, 2018), which-together with the growing mobility and willingness of Hungarians to work or even to migrate abroad in general—has resulted in the lack of workforce in Hungary. The lack of workforce can be felt the most in Western-Hungary, which is caused by the fact that this region is the border region of Austria.

\section{The Situation of Austria as Target Country}

Austria is a successful member of the European Union, with dynamic development figures. The strength and importance of the country are proven on different fields of economy. Its population is growing year by year and due to the continuously rising number of migrants - who actually are willing to take lower valued jobs as well - coming to the country, Austria is less endangered by the lack of workforce in some specific endangered types of professions, and also by the aging itself. Based on the latest statistics of the Austrian Integration Fund (ÖIF, 2018), Austria is one of the key migration-aimed target countries within the European Union: Last year, 154,700 people immigrated into Austria and only 110,119 people emigrated. The forecasts show that the due to the increasing migration - counted with an estimated yearly net increase with about 32,000 persons - and due to the increase in life expectancy, the current population of Austria is supposed to grow from 8.6 to 9.4 million 
people by 2050 (Dialog, 2011). But the actual statistics show that the yearly net increase is actually much higher: In 2017, for example, it was 64,676 (ÖIF, 2017). Austria has its very special pull effect concerning work-related migration in Central- and Eastern-Europe with its low unemployment rate, financial stability, and social welfare system. According to the newest Austrian official statistics in 2017, more than one fifth of the total population (1.97 million people) had migration background (ÖIF, 2018).

\section{Theoretical Background}

Many Hungarian and Austrian researchers have already investigated and analyzed the relations between Hungary and Austria, the advantages of the border region, and the different types of co-operation and their potential outcome (Csapó, 1999; Rechnitzer, 2005; Hárs, 2002; 2009; Hardi, 2009). The main focus earlier laid on the assumption of the number of emigrants (Kapitány \& Rohr, 2013) and the characteristics of the migration activities (Blaskó, 2014); and based on the available data, the analyzes of those being affected by migration for not longer than a year (Blaskó, Ligeti, \& Sik, 2014; Hárs, 2012; Bodnár \& Szabó, 2014). The researches partly touched the field of grouping the migrant workers based on their actual intentions and the reasons of migration, but were not directly focusing on this topic. The findings of Hardi (2005) showed as key reason for work related migration from Hungary to Austria the much higher wages, while the chance to achieve the better social benefits was almost not even present. Another finding carried out by Austrian researchers has also stated that for Hungarian employees working in Burgenland province of Austria, the much higher earning is the explicit motivational factor (Wasserbacher \& Michenthaler, 2007).

Upon analyzing the complete period of the 1990s, Cseres-Gergely (2003; 2005) had found that unemployment and the differences in wages play a role in the migration decision, but only with less importance. According to Kertesi and Köllö (1997), the key reason for the migration is the pull effect of the well-prospering economic region. According to Juhász (2006), besides the push factors of the country of origin the political and the family reasons also appear. The study of Kaczmarczyk and Okólski (2005) declared that in Central- and Eastern- Europe, the current migration behavior is caused by the interaction of three different imbalances: demographical, economical, and political.

\section{The Empirical Research}

In order to get an up-to-date picture about the current situation concerning the work related migration from Western-Hungary to the bordering Austria, the author carried out a quantitative research using an online questionnaire with the help of Google Forms. With the help of a Facebook group (called "Ausztriai Álláslehetőségek-Friss") carefully built up as part of a business service, the Facebook group was followed by 105,000 people, most of whom are Hungarian citizens, either working or living in Austria already, or being already on the search for a job there. All followers of the Facebook group living in Western-Hungary were asked to participate in the research by filling out the questionnaire between the 18th and the 25th of January 2018 and giving the adequate answers on the questions. After the given time was up, the online access to the questionnaire has been blocked. The questionnaires have been processed by the author, the data-coding, their cleaning, and the follow-up work has been done with the help of the SPSS 20.0 statistical programme.

The final number of sample elements has been 611, as four elements have not been adequate to the first and most important criteria of the research; the geographical impoundment, as the respondents were not living in one of the three counties of the Western-Hungarian regions. Before the initiation of the research, a few key 
questions were formulated in advance with the intention to see whether there are changes in the motivating factors for the work related migration from Hungary to Austria, than set in the researches and literature introduced earlier in this study:

Q1: Is salary still the most important for Hungarians upon making the decision to work in Austria?

Q2: Is the social benefit related factor also strong?

Q3: Can other important factors be determined?

Q4: Is it possible to group people based on the factors?

In the following chapters, the author intends to introduce the answers on the questions above presenting the results of the questionnaire.

\section{Description of the Population of the Responders}

The gender of the responders was almost in an equivalent relation, as out of the complete sample $(N=$ 611), we had 310 women and 301 men. The narrow difference in the gender of the responders rises our attention to the fact that nowadays it is already not only the privilege of men to seek work abroad (as it was the case earlier in CEE), but women also appear as independent and dominant persons on the labour market. The respondents $(N=611)$ are mainly aged between 25 and 39 years old; the members of which age group are unfortunately the most active, innovational, and hard-working ones. The great majority $(60 \%)$ of the respondents $(N=611)$ do already have a family with one or two children, which sooner or later leads to the sad fact that the grade of bonding of the people to Hungary gets looser, the children will start to go to school in Austria already, their socializing takes place already abroad, and the chance of complete immigration grows. Ten percent of the respondents already have a temporary residency in Austria and half of them $(N=611)$ are already working there; $80 \%$ of the respondents $(N=611)$ does speak German at some level.

\section{Results Related to Weighing of the Individual Motivational Factors}

The author has analyzed the factors influencing the respondents $(N=611)$ in their choice of working abroad in Austria with the help of eight attitude statements defined by the author at the beginning.

The average values 1 to 5 on the Likert scale below the statements express to what extend the respondents $(N=611)$ agree with them. Based on the results exposited in Figure 1 , the most important motivational factor for work-related migration is the fact that people can earn much more money in Austria than in Western-Hungary. Therefore, the answer on Q1 is definitely "yes".

The second most important factor for them is the chance to improve their German language knowledge, which together with the possibility of higher earning got a result over 4 on the Likert scale. For the responders the third, but still important factor is the chance to improve their professional knowledge. This possible (wished) development can be considered as a brain gain process, which at the end again can lead to another step forward, followed by a potential increase in their salaries. Professional improvement only got a 3.43 on the Likert scale, but can still be regarded as very important, due to the fact that the upcoming factors do not even reach 3 on the scale. As a result of the values given by the respondents on the importance of the improvement needs (both language- and professional knowledge), Q3 gets a clear "yes" answer. Upon introducing the situation of Hungary as a country of origin in this study, the author has stated that there is already a lack of workforce in Western-Hungary on some specific fields. Based on this, it is quite normal that the factor saying that there are no available jobs in Hungary only got 2.79 on the Likert scale. The extent of the social benefits is not a critical 
issue for the respondents; this factor is only the fifth most important out of the eight attitude statements with a value of 2.36 on the Likert scale. This actually answers the Q2 with saying a clear "no": The social benefit related factor is not that important for the respondents intending to work in Austria. At the back, we find the political factors and the temporary solution seekers, both slightly above 2.1 on the Likert scale. And at the very end (already below the value 2) we can find those, who have the intention of getting higher education in Austria.

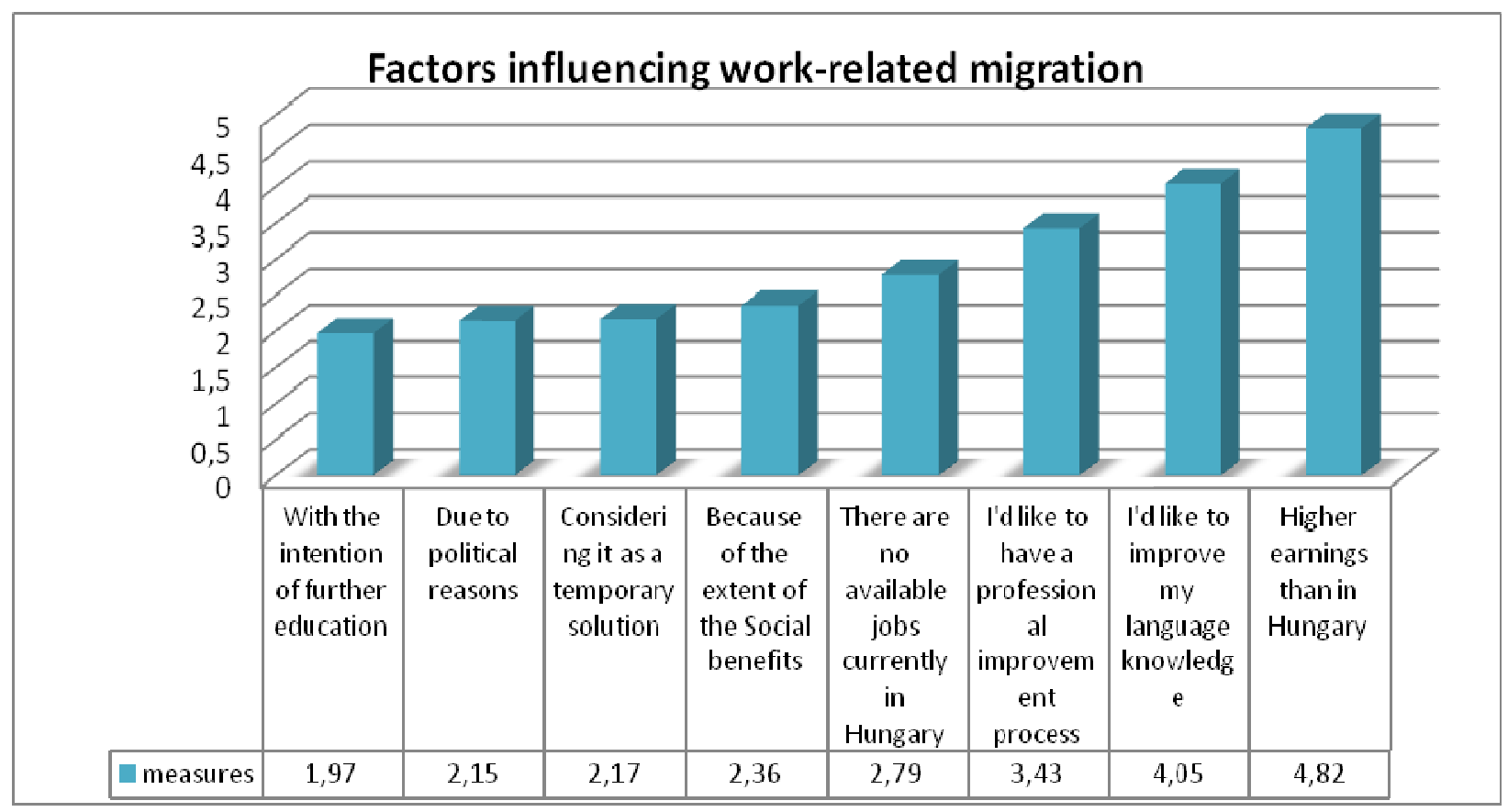

Figure 1. Factors influencing work-related migration. Source: Own research (Kovács, 2018).

\section{Results of the Cluster Analysis}

Q4 is looking for an answer on whether it possible to group people based on the factors. In order to be able to give an accurate answer on this one, the author has made a cluster analysis related to the eight attitude statements, which does group the similar elements. Upon deciding on the number of clusters, it is of key relevance that the groups shall be as heterogeneous as possible, but at the same time, it is important that the numerical differences are not supposed to be too big. The 2 and 3 cluster solutions based on the Ward-method both show too big numerical differences, but based on the frequency tables, the 4 cluster solution is the most optimal, because in this case, the cluster members do stand the closest to each other. The best tool for defining the group of clusters is the discriminant analysis. Based on the mean and deviation of the individual variables of groups and total, we can define the point of view of the members of the 4 clusters related to the eight attitude statements.

The attitude statements and their values in each cluster are summarized in Table 1. As stated earlier, not only the high values but also the low once can be of specific importance. As the outraging values have been highlighted, we can see that according to the members of Cluster 1, the higher earnings have key priority, followed by the need for the improvement of their language skills, and quite interesting: The political reason as factor is also very important for them. 
For the members of Cluster 2, the higher earnings are of highest importance, and just like for the members of Cluster 1, the improvement of their foreign language skills is on second place. On Rank 3, they also want to improve their professional knowledge and a very low value (1.21) is given by them to the political reasons, which means this is indeed very uninteresting for them.

Cluster 3 very much differs from the previous two, although the higher salary is for them also a very crucial issue. Concerning the remaining seven attitudes, they gave quite low values: Four attitudes are below 2 and three of them actually only slightly above 1 . We can clearly see that the members of this cluster actually really are only keen on earning "big" money in Austria.

Cluster 4 again puts the higher earnings on first place, just like the members of all other clusters, but for them the higher extent of the social benefits gets on Rank 2. Political reasons, the intention to participate in further education and considering working in Austria only as a temporary solution, are undervalued by the members of this cluster, therefore they do not regard these factors as important.

The four clusters have some relevant points in common: For all of them, the first and most critical motivational factor for working abroad in Austria is the possibility to legally earn much more money, than they can earn in their homeland. The second most important factor is the possibility to improve their language knowledge abroad, basically in a mother-tongue environment. Most irrelevant is the work-related migrational activity due to political reasons and the high importance of the different extent of the social benefits can also not be determined: It did not even get an average ranking based on the answers.

As we can see, indeed people can be grouped based on factors into clusters. Q4 is this way answered with a clear "yes".

Table 1

Summary of the Four Clusters Related to the Attitude Statements

\begin{tabular}{|c|c|c|c|c|c|c|c|c|}
\hline \multirow{2}{*}{ Attitude statements } & \multicolumn{2}{|c|}{ Cluster 1} & \multicolumn{2}{|c|}{ Cluster 2} & \multicolumn{2}{|c|}{ Cluster 3} & \multicolumn{2}{|c|}{ Cluster 4} \\
\hline & Value & Members & Value & Members & Value & Members & Value & Members \\
\hline There are no available jobs currently in Hungary. & 3.03 & 181 & 2.79 & 248 & 2.36 & 72 & 2.64 & 106 \\
\hline Higher earnings than in Hungary. & 4.78 & 181 & 4.83 & 248 & 4.76 & 72 & 4.91 & 106 \\
\hline $\begin{array}{l}\text { I would like to have a professional improvement } \\
\text { process. }\end{array}$ & 3.61 & 181 & 3.92 & 248 & 1.58 & 72 & 3.14 & 106 \\
\hline I'd like to improve my language knowledge. & 4.34 & 181 & 4.26 & 248 & 3.11 & 72 & 3.67 & 106 \\
\hline Considering it as a temporary solution. & 2.53 & 181 & 2.01 & 248 & 2.79 & 72 & 1.53 & 106 \\
\hline Due to political reasons. & 3.99 & 181 & 1.21 & 248 & 1.21 & 72 & 1.73 & 106 \\
\hline With the intention of further education. & 2.52 & 181 & 2.03 & 248 & 1.07 & 72 & 1.47 & 106 \\
\hline Because of the extent of the social benefits. & 2.7 & 181 & 1.85 & 248 & 1.08 & 72 & 3.85 & 106 \\
\hline
\end{tabular}

Source: Own research (Kovács, 2018).

\section{Conclusion}

The analyzes of the factors with the help of attitude statements influencing the decision of taking a job in Austria, has clearly proven that for the people living in Western-Hungary the most dominant argument is the much higher salary they can get on a monthly basis. The higher social benefits are not that important as thought prior to the research, and except for the need of the Western-Hungarians to improve their German language knowledge and their professional skills, no other dominant factor can be determined. The current political situation in either Hungary or Austria has raised very low attention, and almost no one chooses Austria instead 
of Hungary as a temporary solution. Also, concerning the further education, the author has got a relatively negative feedback, meaning that it cannot be detected as a key motivational factor for the people of Western-Hungary. Just as described at the beginning of this study upon introducing Hungary as a COO country in this case, the fact that we face shortages in the number of potential employees was returned in the answers, as members of the four clusters did not rank very high the statement that there are no jobs available currently in Hungary.

With the help of cluster analyzes, the author has proven that people can actually be grouped based on their motivation and intention why to work in Austria; the author was able to set up and deeper analyze four clusters. In general, the paper has again verified many of the previous literature (also stated in the study), searching for the key motivational factors upon taking the decisions to work in a foreign country abroad.

\section{References}

Barta, G., \& Kovács, E. (2017). Older persons on the Austrian and Hungarian labor markets. In Karlovitz (Ed.), Essays in economics and business studies. Komarno: International Research Institute.

Blaskó, Z. (2014). Surveying the absentees: Surveying the emigrants. Seemig Working Papers Series 4, Hungarian Demographic Research Institute, Budapest.

Blaskó, Z., Ligeti, A. S., \& Sik, E. (2014). Magyarok külföldön: Mennyien? Kik? Hol? Társadalmi Riport, 351-372. Retrieved from http://old.tarki.hu/adatbank-h/kutjel/pdf/b337.pdf

Bodnár, K., \& Szabó, L. T. (2014). A kivándorlás hatása a hazai munkaerőpiacra. MNB-tanulmányok 114, Magyar Nemzeti Bank, Budapest, 2014. Retrieved from https://www.mnb.hu/letoltes/a-kivandorlas-hatasa-a-hazai-munkaeropiacra.pdf

Csapó, T. (1999). Határ menti együttmüködések a munkaerőpiac területén, különös tekintettel Vas és Zala megyére. In M. Nárai and J. Rechnitzer (Eds.), Elválaszt és összeköt: A határ (pp. 269-295). Pécs: MTA RKK.

Cseres-Gergely, Z. (2003). The effects economic incentives on residential mobility and migration in Hungary, 1990-1999: Society and Economy. Journal of the Budapest University of Economic Sciences and Public Administration, 3, 351-382.

Cseres-Gergely, Z. (2005). County to county migration and labour market conditions in Hungary between 1994 and 2002. Zeitschrift für ArbeitsmarktForschung (ZAF), 37(4), 425-436.

Dialog, B. I. (2011). Auswirkungen der demographischen Entwicklung auf Arbeitsmarkt und soziale Systeme: Positionen der österreichischen Sozialpartner. Retrieved from http://www.sozialpartner.at/wp-content/uploads/2015/08/Bad-Ischl-2011-Kurzversion.pdf

Hardi, T. (2009). Határon átnyúló ingázás, munkavállalás egy magyar-osztrák és szlovák-magyar példán keresztül. In T. Hardi, Z. Hajdú,and I. Mezei (Eds.), Határok és városok a Kárpát-medencében. Györ-Pécs: MTA RKK.

Hárs, Á. (2002). A munkaerő migrációja és az uniós csatlakozás (Labour migration and the enlargement of the EU) KOPINT-DATORG Working Papers 34, p. 41, Budapest.

Hárs, Á. (2012). A munkaerő migrációja Magyarországon a kilencvenes és a kétezres években: Bevándorlás és elvándorlás a munkaerö-felmérés adatai alapján. Budapest: MTA KRTK KTI.

Hárs, Á. (kutatásvezető). (2009). Magyarok az osztrák munkaerőpiacon: Ingázók, bevándorlók, munkaerő-migránsok? Szintetizáló Tanulmány, Kutatási Zárójelentés, p. 76, Budapest.

Hauptverband der Österreichischen Sozialverischerungsträger. (2018). Statistische Daten aus der Sozialversicherung: Beschäftigte in Österreich. Retrieved from http://www.sozialversicherung.at/cdscontent/load?contentid=10008.600539\& version $=1539602425$

Juhász, J. (2006). Migráció és feketemunka Európában: Migration and Irregular Work in Europe (MIGIWE). Záró Tanulmány, MTA Földrajztudományi Kutatóintézet, Panta Rhei Társadalomkutató Bt. Budapest.

Kaczmarczyk, P., \& Okólski, M. (2005). International migration in Central and Eastern Europe: Current and future trends. New York: UN Population Division, Department of Economic and Social Affairs.

Kapitány, B., \& Rohr, A. (2013). A Magyarországon állandó lakcímmel rendelkező 18-49 éves magyar állampolgárok. Korfa, 13(3). Budapest: KSH-NKI.

Kertesi, G., \& Köllő, J. (1997). Reálbérek és kereseti egyenlőtlenségek, 1986-1996: A bérszerkezet átalakulása Magyarországon, I. Közgazdasági Szemle, 7-8, 612-634. 
Kotowska, I. E. (2006). Older workers in the labour market and retirement policies. In R. Palomba, and I. E. Kotowska (Eds.), The economically active population in Europe: Population Studies, No. 40 (pp. 55-89). Strasbourg: Council of Europe Publishing.

OECD and EU. (2014). Matching economic migration with labour market needs. Paris: OECD Publishing. Retrieved from $\mathrm{http} / /$ www.oecd-ilibrary.org/social-issues-migration-health/matching-economic-migration-with-labour-market-needs_97892 64216501-en

Österreichischer Integrationsfond (ÖIF). (2014). Migration \& integration. Zahlen.daten.indikatoren. Retrieved from https:/www.bmeia.gv.at/fileadmin/user_upload/Zentrale/Integration/Integrationsbericht_2014/migration_integration2014-we b.pdf

ÖIF. (2017). Migration \& integration. Zahlen.daten.indikatoren Retrieved from https://www.integrationsfonds.at/fileadmin/content/AT/Downloads/Publikationen/Statistisches_Jahrbuch_migration_integrati on_2017.pdf

ÖIF. (2018). Migration \& integration. Zahlen.daten.indikatoren. Retrieved from https://www.integrationsfonds.at/fileadmin/content/AT/Downloads/Publikationen/Statistisches_Jahrbuch_2018.pdf

Rechnitzer, J. (2005). Az osztrák-magyar határ menti együttmüködés múltja, jelene. Tér és Társadalom, 2, 7-29.

Van der Gaag, N., \& Van der Erf, R. (2008). EUROPOP 2008 compared with EUROPOP 2004. European Observatory on Demography and the Social Situation: Demography Network, European Commission, Brussels.

Wasserbacher, H., \& Michenthaler, G. (2007). Entwicklung des Arbeitsmarktes im Grenzraum Burgenland/Ungarn während der Übergangsperiode. Retrieved from http://expak.at/expak/img/uploads/expak636.pdf

World Bank. (2011). Migration and remittances Factbook. Retrieved from https://siteresources.worldbank.org/INTLAC/Resources/Factbook2011-Ebook.pdf 